\title{
Thomas F. Torrance: Theology and mission in practice
}

\begin{tabular}{|c|c|}
\hline \multicolumn{2}{|l|}{$\begin{array}{l}\text { Authors: } \\
\text { Caroline G. See } \\
\text { Daniel Lioy } 2,3,4 \\
\text { Rikus Fick }^{3}\end{array}$} \\
\hline \multicolumn{2}{|c|}{$\begin{array}{l}\text { Affiliations: } \\
{ }^{1} \text { Department of Theology, } \\
\text { Presbyterian University of } \\
\text { East Africa, Kenya }\end{array}$} \\
\hline \multicolumn{2}{|c|}{$\begin{array}{l}{ }^{2} \text { Religious Studies } \\
\text { Department, Department of } \\
\text { Theology, Marylhurst } \\
\text { University, United States }\end{array}$} \\
\hline \multicolumn{2}{|c|}{$\begin{array}{l}{ }^{3} \text { Faculty of Theology, } \\
\text { North-West University, } \\
\text { South Africa }\end{array}$} \\
\hline \multicolumn{2}{|c|}{$\begin{array}{l}{ }^{4} \text { The South African } \\
\text { Theological Seminary, } \\
\text { South Africa }\end{array}$} \\
\hline \multicolumn{2}{|c|}{$\begin{array}{l}\text { Corresponding author: } \\
\text { Caroline Seed, } \\
\text { cgseed@outlook.com }\end{array}$} \\
\hline \multicolumn{2}{|c|}{$\begin{array}{l}\text { Dates: } \\
\text { Received: } 10 \text { Feb. } 2016 \\
\text { Accepted: } 13 \text { July } 2016 \\
\text { Published: } 19 \text { Oct. } 2016\end{array}$} \\
\hline \multicolumn{2}{|c|}{$\begin{array}{l}\text { How to cite this article: } \\
\text { Seed, C.G., Lioy, D. \& Fick, R., } \\
\text { 2016, 'Thomas F. Torrance: } \\
\text { Theology and mission in } \\
\text { practice', In die Skriflig } 50(1) \text {, } \\
\text { a2098. http://dx.doi. } \\
\text { org/10.4102/ids.v50i1.2098 }\end{array}$} \\
\hline \multicolumn{2}{|c|}{$\begin{array}{l}\text { Copyright: } \\
\text { (C) 2016. The Authors } \\
\text { Licensee: AOSIS. This } \\
\text { is licensed under the } \\
\text { Creative Commons } \\
\text { Attribution License. }\end{array}$} \\
\hline \multicolumn{2}{|l|}{ Read online: } \\
\hline 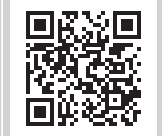 & $\begin{array}{l}\text { Scan this QR } \\
\text { code with your } \\
\text { smart phone or } \\
\text { mobile device } \\
\text { to read online. }\end{array}$ \\
\hline
\end{tabular}

This article proposes that scholarship needs to take into account the intensely missional and practical nature of T.F. Torrance's life and work. Using primary sources, it isolates mission to the Qiang in China as the area in which personal mission practice and theology coincide. It shows that Torrance's theology of divine-human communion is rooted in the missio Dei, expressed in the nature of the perichoretic interrelations of the ontological Trinity and the mission of the economic Trinity in the world through the covenant history of Israel. This concept is illustrated practically in the mission history of the Qiang. A holistic concept of mission and theology is therefore at the heart of both Torrance's biography and theology.

\section{Introduction}

Scholarly research into the theology of Thomas Forsyth Torrance (1913-2007) has increased significantly in the years since his death. Much of the research has focused on his intellectual output and scientific theology (see e.g. Hanna 2004; Munchin 2011; Yom 2013). To date, no significant research has been done to unite his theology and mission practice in spite of the warning by McGrath (1999:237) of the danger of concentrating on Torrance's intellectual achievement to the detriment of the biography that shaped his theology. Colyer (2001:51) noted the significance of Torrance's mission-shaped biography, but saw his mission experience in China as a child (1913-1927) and again in retirement (1984-1994) as 'bookends' to his life. However, if McGrath's warning is to be taken seriously, Torrance's missional biography needs to be considered not as distinct from, but integral to his theological output. To date, the missional nature of much of Torrance's dogmatic and biblical theology has largely remained unexplored. ${ }^{1}$ In this article, Torrance's theology of divine-human communion is considered from a missional perspective that unites his biography and theology in a unified whole through the missio Dei. ${ }^{2}$

\section{Torrance's missional biography Combining mission history and dogmatic reflection}

This article uses primary sources to evaluate the contribution of the Torrance family's mission history in China to the development of Torrance's theology and practical mission involvement. ${ }^{3}$ This is not to presuppose that Torrance's biography should be seen as the source of his theology, an approach that would run counter to Torrance's conviction regarding the objective nature of truth. ${ }^{4}$ Rather, the purpose is to highlight the distinctively missional nature of Torrance's theology of divine-human communion and to suggest historical-biographical as well as theological reasons for this emphasis. Missiologists, Tiénou and Hiebert (2005:122) maintain, 'All theologies are embedded in worldviews that shape the way we see things. There are no culture-free and historyfree theologies'. Mission historian, Andrew Walls (1997:45) argues that our experiences and relationships influence the development of our theological perceptions. The purpose of this article

1.With the exception of a short article by Ziegler (2008).

2.Torrance's understanding of the missio Dei should be seen in its historical context. His earliest work on the mission of the church was a discussion on volume 1 and 2 of the Studies, prepared in 1948 for the First General Assembly of the WCC (Amsterdam). Torrance (1959b:214) writes, 'the Church continues in the apostolic succession ... in the mission of Christ who is himself the Apostle from the Father, and who commissions his Church in the same Apostolic mission'. This shows that in 1948 Torrance held a view of the Trinitarian nature of the mission of God and the church - a perspective that he retained in the post-Willingen (1952) period, when the nature of the missio Dei was also seen as God acting in the secular world without the participation of the church. For further discussion on the the missio Dei was also seen as God acting in the secular
missio $1991: 379)$ and Wright (2006:62).

3.Primary sources archived in the Thomas F. Torrance Manuscript Collection, Princeton Theological Seminary.

4.This is contra the narrative theology approach of McClendon's Biography as Theology: How Life Stories can Remake Today's Theology (2002). McClendon (2002:vii) claims, 'There is no foundational truth available apart from actual life ... upon which Christian theology can once and for all found its doctrines.' Torrance (1969:307) firmly held to the objectivity of propositional truth about God. 'In theology we have to do with a divine Object that demands and creates reciprocity so that our knowledge of God involves right from the start a union and not a disjunction between subject and object, and yet a union in which God is not entangled in our subjectivity.' Theology is not created from subjective experience. However, theology must always have its practical outworking in the life and mission of God's people, the church.

Note: The subject matter is drawn from a PhD thesis submitted to North-West University, Potchefstroom campus. Seed, Caroline G. 2016, The missional nature of divine-human communion: T.F. Torrance and the Chinese church. PhD thesis, Faculty of Theology, North-West University, Potchefstroom. 
is therefore to uncover the historical-cultural background that helped to shape the development of Torrance's theology of the missional nature of divine-human communion and to trace the practical outworking of that theology in his personal mission engagement. In order to do this, this article will compare Torrance's personal mission history with his theology of divine-human communion. It will be seen that it is the ontological location of the missio Dei in the interrelations of the triune God and the economic outworking of the missio $\mathrm{Dei}$ in the incarnation that unites mission history and dogmatic reflection in the Torrance corpus.

The mission history of T.F. Torrance begins with his parents, Thomas and Annie Torrance, who served as missionaries in Sichuan Province between 1895 and $1934 .{ }^{5}$ Their influence on the missional and theological development of their family provides an early 20th century missionary movement context for the development of Torrance's persona. This era of mission history, together with the primary sources from which it is derived, belongs to what Noll (1998:105) calls the 'premodern' period, characterised by propositional truth as well as ideological and tribal bias. This 'premodern' evangelical bias needs to be borne in mind in all considerations of the influence of the Torrance family history on the shaping of T.F. Torrance's theology. ${ }^{6}$

\section{The Torrance family in China (1895-1934)}

Thomas Torrance Senior (1871-1959) was born in Scotland to a farming family who were committed members of the established Church of Scotland. In his teenage years, he felt called to engage in evangelistic mission overseas, but his parents refused to support him. However, Torrance Senior defied his parents' wishes and wrote them a letter explaining the priority of his call. He then undertook paid employment to support himself through mission and medical training (1892-1895). The decision was momentous both for him and his future family. In a letter to his father in 1929, T.F. Torrance recalls the impact that his father's letter had on him when he was shown a copy, 'I often think of the letter that you let me read; that letter you sent to your mother and father informing them of your call to the mission field ...' (Torrance 1913-2007, Manuscript Collection Box 11). An awareness of his father's call to mission and the sacrifices that it involved was to play an important part in Torrance's own sense of call to mission.

After completion of his studies in 1895, Torrance Senior joined the China Inland Mission (CIM) and was sent as an evangelist to Chengdu in Sichuan Province. CIM was atypical of missions in the late 19th century, because it aimed to evangelise the whole of China through the preaching of the

5.Annie Elizabeth Sharpe arrived in Guan Xian, 30 miles north of Chengdu, in 1907 under the auspices of China Inland Mission. She returned 7 years before her husband.

6.From a family background in early 20th century evangelical mission, Torrance developed a nuanced understanding of what it means to be evangelical. Rooting his theology in the Nicene tradition rather than 20th century fundamentalist propositions, Torrance (1982:17-19) maintained that evangelical theology is both realist and a posteriori, because it is concerned with bringing all things into conformity with God's 'self-revelation in the incarnate life and work of Jesus Christ'. As such, evangelical theology is an 'evangelising theology' that is concerned with the 'winning and transforming of the human mind' as well as human society and culture, 'through conformity to the mind of Christ' (Torrance 2009:444). gospel without setting up educational institutions (Latourette 1929:386). Although he was a committed evangelist, Torrance Senior found his policies in conflict with those of CIM as he believed strongly in theological training for converts (Torrance 1913-2007, Manuscript Collection Box 6). This would eventually lead to a falling out with the leadership of CIM and Torrance Senior's return to Scotland in 1909.

In Scotland, Torrance Senior attended the 1910 Edinburgh Mission Conference where the American Bible Society (ABS) asked him to return to China to assist with the distribution of Bibles and tracts on its behalf. Torrance agreed on the condition that he could continue to work in Sichuan Province (Torrance 1913-2007, Manuscript Collection Box 7). In 1911, he therefore returned to Chengdu under the auspices of the ABS and married Annie Elizabeth Sharpe, an Anglican working with CIM, also stationed in Sichuan. Together they set up house in Chengdu where Thomas Forsyth Torrance, their second child, was born in 1913.

The early life of T.F. Torrance and his five siblings (born between 1912 and 1924) was characterised by assimilation into Chinese culture. They lived in the Chinese area of the city, spoke the local dialect and interacted with Chinese people, although they attended the Canadian Mission School on the grounds of the West China Union University in Chengdu. Torrance had vivid memories of passing the Chengdu leper colony on his way to school every day and noticing the deformation of limbs and facial features on the sufferers (Torrance 2009:440). In addition, the early 20th century was a time of turbulence in China and the Sichuan Province, especially, was affected by the problems of rule by warlords. There were frequent periods of unrest and violence during which foreigners, living in Chinese areas, had to flee into the safety of mission compounds. The difficulties of life in Chengdu at that time would leave indelible impressions of China on Torrance's mind (Torrance 2009:440).

The Torrance children were brought up in an atmosphere of zealous evangelical mission - typical of the early 20th century. Torrance describes his father as an 'indefatigable evangelist' - a claim that is substantiated by evidence in a letter from John Sykes, General Secretary of the ABS (Torrance 1913-2007, Manuscript Collection Box 6 \& 10). Torrance Senior saw his children as co-workers and expected them to participate fully in daily Bible reading and prayer for the salvation of the people among whom they lived. Their mother was equally influential, teaching them to read the Word of God in such a way as to expect to hear God speak to them through it (Torrance n.d.). In his autobiographical memoirs, Torrance comments that from his earliest years he inherited from his parents a vivid sense of belief in God (Torrance 1913-2007, Manuscript Collection Box 10).

During the latter half of the 1920s, life became difficult for missionaries in Sichuan Province because of the frequent clashes between the nationalist government and Communist party troops. In 1927, when Torrance was 14 years old, antiWestern sentiment led to kidnappings and murder of 
missionaries in the region. The British Consul ordered all missionaries out of Sichuan and so the Torrance family fled under crossfire down the Yangtse River to Shanghai where they joined the general exodus of missionaries returning home. Torrance Senior, however, felt that his work in China was not finished. In 1928, he returned to Sichuan Province, leaving Annie and the children in Scotland. He eventually retired from China in 1934.

\section{Mission to the Qiang (1917-1934)}

One aspect of Torrance Senior's work in China in particular was to have a significant impact on his eldest son. This was the evangelistic work among the Qiang ${ }^{7}$ minority group whom Torrance Senior had first encountered briefly in 1917 on a mission trip into the upper Min River valley, in the areas bordering on Tibet (Torrance 1913-2007, Manuscript Collection Box 6). ${ }^{8}$ On his first trip, Torrance Senior found an inscription dating the Qiang back to King Yu of the Hsia dynasty (c. 2205 BCE). ${ }^{9}$ He observed that the Qiang were distinct from the Han Chinese and had often come under attack as outsiders. As a result, they had withdrawn to live in inaccessible villages with stone watchtowers. Taking careful notes on their belief system and collecting artefacts, he returned each year to preach the gospel and research their religion. In his teenage years, T.F. Torrance accompanied his father and participated in the mission work. This experience was to engender in him a passionate sense of 'call' to become a missionary. In a letter to a friend in 1985, Torrance recalls, 'I had always wanted to be a missionary on the Tibetan border of Sichuan, in the upper Min valley, where my father had worked so long' (Torrance 1913-2007, Manuscript Collection Box 159). Torrance made no secret of this desire, even as a teenager. In a letter to Torrance Senior in 1935, T.E Plewman, a missionary from Chengdu, wrote to ask if T.F. Torrance would return to work among the Qiang. He clearly expected Torrance to fulfil his declared intention (Torrance 1913-2007, Manuscript Collection Box 160).

By 1920, Torrance Senior had collected enough material to publish an article on the Qiang (Torrance 1920). In it, he describes the religion of the Qiang as monotheistic, with a religious system analogous to ancient Israelite practice. His evidence for this was the scapegoat that carried away the sins of the community ( $\mathrm{Lv} 16)$ and the use of blood for cleansing. He describes a ritual in which an unblemished bullock was sacrificed on an altar of uncut stone and its blood sprinkled on a white stone (lopee) that represented the pure and holy deity. The sprinkling of the blood made the participants holy and led to the descent of the Shechinah or Spirit of Heaven. ${ }^{10}$ From this, he concluded that the Qiang must be of Israelite origin. The mission community reacted favourably to

7.Pinyin transliteration. In the early 20th century, it was written Chi'ang.

8.T.F. Torrance (1988:1) incorrectly recorded the year as 1916.

9.Torrance Senior records finding an inscription to this effect in Shiniushan, Sichuan Province in 1919.

10.The Shechinah is the word used by the Qiang for the Spirit of Heaven -first reported by Reverend Thomas Torrance in a letter to Dr. Hynes of the American Bible Society, 12th August 1919 (Torrance 1913-2007, Manuscript Collection Box 6). the article. ${ }^{11}$ Writing in the Church Missionary Outlook, the Church Missionary Society (CMS) Secretary for Western China, Reverend V. Donnithorne (1922:112-114), commended Torrance Senior's interpretation of the religion of the Qiang and urged CMS supporters to raise funds to send more missionaries into the region. ${ }^{12}$

One of the difficulties Torrance Senior had in understanding Qiang religion was his inability to speak their dialect. However, in 1920 a young man, who had exposure outside the Qiang community, agreed to come to Chengdu for Bible study. As Torrance Senior read the Pentateuch and John's Gospel with him, the young man compared the Qiang beliefs with the biblical narrative and claimed that the Qiang were true Israelites for whom Jesus Christ is the fulfilment of their sacrificial rituals. His claims for Israelite descent were based on the Qiang tradition of hanging 12 banners in memory of the 12 sons of their ancestor whom he identified as Jacob. As a result, he became a Christian and was baptised 'Isaac' after his ancestor and 'Whiteheart' because of his concern for ritual purity (Torrance 1913-2007, Manuscript Collection Box 4). After his conversion, Whiteheart accompanied Torrance Senior on his annual visits to the Qiang, acting as interpreter. During a visit to a village called Oir, he introduced a Qiang priest who explained the rituals and showed them a Nehushtan pole and a sacred roll of white paper with a skull on top. ${ }^{13}$ The priest explained that the skull showed that the Word of God (represented by the scroll) was actually a person, the 'sin bearer' (Abba Malach), whom they believed would come into the world to bear their sins (Torrance 1913-2007, Manuscript Collection Box 10).

After the explanation, Torrance Senior read to the priest from the book of Leviticus. Torrance recalls, 'When father read the Levitical instructions in the Old Testament, the priest jumped off his bench and said those are the lost Scriptures which had been represented by the white scroll' (Torrance 1913-2007, Manuscript Collection Box 10). Torrance Senior then read from John's Gospel and explained that while the Qiang were in China, the 'sin bearer' had come in the person of Jesus Christ. Torrance recalls:

The Oir priest believed the good news of the Gospel which my father proclaimed to him, and he and his sons were baptised. That is an experience I shall never forget. (Torrance 1913-2007, Manuscript Collection Box 10).

This appears to have been an experience of profound significance to T.F. Torrance and possibly the source of his personal call to mission among the Qiang.

When Torrance Senior returned to Sichuan in 1928, Torrance continued to correspond with him from Scotland over the Qiang mission and the church at Tongmenwai where he had assisted his father with evangelism. Torrance's letters show

11.Although McGrath (1999:16) states that the theory did not find wide acceptance at that time.

12.This initiative was not successful (Church Missionary Society Archive 1869-1949).

13.The Nehushtan was a serpent coiled on a pole. Torrance Senior believed was symbolic of the bronze serpent of Numbers 21:9. 
that he had imbibed from his father a love for the Qiang people and for mission among them (Torrance 1913-2007, Manuscript Collection Box 11). As he matured in Scotland and went to Edinburgh University to study Classics and Philosophy, he was driven by a sense of preparation for a return to mission in China, participating in student outreaches to non-Christians and preaching evangelistic sermons (Torrance 1913-2007, Manuscript Collection Box 10).

Torrance Senior continued to work in the Qiang villages, although in the 1930s the security situation in and around Chengdu deteriorated. However, on his last visit in 1934, he was encouraged by what seemed to be a spirit of revival in the region. In response to the preaching of the gospel, hundreds of Qiang came down the mountains to be baptised at the main church in Tongmenwai (Torrance 1913-2007, Manuscript Collection Box 4). When he returned to Scotland in 1934, Torrance Senior left behind seven congregations under the leadership of Isaac Whiteheart. However, in 1935 the communist forces of Mao Zedong passed through the upper Min valley and destroyed most of the churches. Whiteheart and other Qiang Christians were killed and all the Bibles were burnt, with the exception of a Bible buried in a cave. After the communist forces left, the only surviving member of the church at Tongmenwai, Huang Taiqing, dug up the Bible and sent it to the Torrance family in Scotland as a symbol of the resurrection of the church in China. Thus, through this Bible the concept of the future 'resurrection' of the Qiang church remained within the consciousness of the Torrance family throughout the years in which they were unable to return to China.

Parfitt and Semi (2013:20-21) observe a development in Torrance Senior's theological interpretation of the origins of Qiang religion. In his 1920 article, he suggested that they were one of the lost tribes of Israel, but also, and somewhat inconsistently, both inheritors of and the source of Jewish religious practice. By the time of his return to Scotland and the publication of his book in 1937, Torrance Senior had resolved that the Qiang were ancient Israelites who had been sent by God to bear witness to the Chinese of the need for a blood sacrifice to take away sins. They were therefore God's first missionaries to China (Torrance 1937:121). From this, he developed a theology of the Israelites' priestly mission to the world. Parfitt and Semi (2013:21) report that initial reaction to the 1937 publication drew favourable reviews in the press. ${ }^{14}$ The story of the ancient Israelite missionaries to China seemed to catch the imagination of mission supporters.

After his father's return to Scotland, Torrance pursued theological studies at New College Edinburgh and came under the influence of Hugh Ross Mackintosh (1870-1936) whose understanding of the integral nature of theology and mission particularly influenced him (Torrance 1913-2007, Manuscript Collection Box 10). Mackintosh's teachings deepened the call to return to China as a missionary, yet also stirred a desire to engage in theological education as mission.

14.The Scottish Geographical Magazine called it 'the missionary book of the century' The English Churchman and St James Chronicle and the Times Literary Supplement were equally complimentary.
When Torrance eventually decided in 1936-1937 to turn his call to mission in China to pastoral work and theological education, he did not feel that he had been disobedient. He comments, 'Even as a professor of theology, I have always tried to be a missionary' (Torrance 1913-2007, Manuscript Collection Box 10). Torrance never lost his sense of call to mission among the Qiang, but it was focused in another direction. Although Western mission in China continued under sufferance until 1951, when missionaries were effectively expelled from the country, the opportunity to return to the Qiang churches was politically impossible. Torrance's participation in theological education in Scotland and beyond gave him a platform for engagement in theology as mission until there was an opportunity to return to China. ${ }^{15}$

\section{The resurrection of the Qiang church (1984-1994)}

The opportunity arose in 1984 with the end of the Cultural Revolution. During the interim period, a concern for the mission history of China had led to renewed interest in the Qiang and the republication of Torrance Senior's book (1988). ${ }^{16}$ Uncertainty about the feasibility of Torrance Senior's claims regarding the Jewish origins of the Qiang led the publishers to request that Torrance visit the region and engage in further research. ${ }^{17}$ Torrance therefore sought permission from the Chinese authorities to visit Chengdu in May 1984 and applied for a local permit to visit the Qiang areas. Although he was only able to reach the main town, Songpan, he ascertained that there was a Qiang house church in Weichou led by Huang Taiqing. He learnt that the Christians had no Bibles and the church building had been requisitioned as a library. After this brief initial visit, Torrance returned to Scotland with a threefold objective: to ensure that Chinese Christians had access to the Bible once again; to enable the Qiang church to repossess church buildings; and to prepare for the future leadership of the Qiang church by supporting theological education in the region.

Torrance immediately put together a proposal for the printing of Bibles in China. In 1985 an agreement was signed between the United Bible Societies and Amity Foundation, and in 1987 a Bible printing press was opened in Nanjing. By the time of Torrance's death in 2007, 50 million Bibles had been printed

15.Elmer Colyer (2001:36) speaks of the mission of Torrance's theology as the 'evangelization of Western culture'. Torrance believed that his task as a theologian was to evangelise the philosophical roots of the Western worldview.

16.Daniel Shaw, a Jewish publisher from Chicago, republished the book in 1988.

17.Significant in the criticism of Torrance's theory regarding the Qiang was the publication of the work of anthropologist Reverend David C. Graham (1958) publication of the work of anthropologist Reverend David C. Graham (1958). Graham had worked with Torrance Senior gathering specimens and artefacts in the
Qiang regions in the 1920 s, but subsequently refuted Torrance Senior's conclusions. Thomas F. Torrance was asked by his publisher to refute Graham's claims that his father's 1937 conclusions were driven by a 'deep obsession' about the Jewish inheritance of the Qiang. Graham proposed that they were, in fact, descended from the aboriginal peoples of China. Torrance strongly rejected the criticisms of his father's work, maintaining that his father had not claimed that they were Jews, but ancient Israelites. Neither did he convince them that they were Jews in order to convert them. He pointed to his father's 30 years of experience in the area, his own experience of the monotheism of the Qiang and the archeological and ethnological data that Graham has collected with his father. He also pointed to ethnological data that Graham has collected with his father. He also pointed to research by Prof Daniel Sheets to the effect that the Qiang were of Middle Eastern origin (Torrance 1913-2007, Manuscript Collection, Box 120). In a later inclusion in the Biographical Dictionary of Chinese Christianity T.F. Torrance (2005) wrote that his father had worked among the Qiang tribes, 'who were evidently the remnants of an ancient immigration from the Middle East', showing that he retained his father's view that the Qiang had emigrated from the Middle East and did not accept Graham's conclusions. 
in China. This is undoubtedly Torrance's greatest mission achievement and one that he felt satisfied with, because it gave him the opportunity to realise his call to continue his father's work in China. He comments, 'I am sure that my dear father knows that in this way his form of missionary activity continues in China and that one of his sons had a part in it' (T.F. Torrance 2001:304).

In 1986, Torrance returned to Chengdu in order to assist in the re-establishment of the Qiang church. At this time, he was accompanied by Israeli anthropologists who conducted research into the Jewish origins of the Qiang and concluded that they were descendants of Joktan from a pre-Mosaic period (Gn 10:26; Torrance 1913-2007, Manuscript Collection Box 163). Torrance handed over the title deeds that had been in his father's possession to the local authorities in the hope that the government would pay rent for the confiscated property. At the same time, he gave the 'resurrected Bible' to Taiqing. In order to secure the future of the church, he instructed Taiqing to identify a suitable person for theological training. He also visited the Chengdu Theological Seminary and obtained assurances that they would train a Qiang pastor. These interventions gave Torrance a sense of fulfilment of call: 'I felt that I had been sent back by the Lord to help the Chi'ang to rekindle the flame of their Christian faith and start rebuilding the church in their midst' (Torrance 1913-2007, Manuscript Collection Box 10).

In the years between 1986 and his last visit to Chengdu in 1994, Torrance engaged in correspondence with many Chinese people whom he had met during his trips - most notably student teachers from the Aba Teachers' College in the Qiang region where he gave a lecture on the scientific theology of light in 1986. In all his correspondence, he shows an evangelist's concern for the conversion of the students and it appears that several became Christians as a result of his correspondence with them (Torrance 1913-2007, Manuscript Collection Box 162).

In 1994, Torrance made a final trip to Chengdu in order to encourage his converts and to facilitate the rebuilding of the Qiang church that had run into bureaucratic difficulties. He carried money with him to hand over to Taiqing, but was unable to do so, because the Qiang had not obtained permission to build. One of the problems was the lack of a trained pastor to lead the church. Unfortunately, no one suitable had been found. In the end, Taiqing whitewashed a house (as a symbol of purity) and set it apart for worship. Torrance continued to support Chengdu Seminary in the hope that Qiang and other minority pastors would be trained there. In his later years, he continued to keep the Qiang in his prayers (Torrance 1913-2007, Manuscript Collection Box 161).

Today, anthropologists do not uphold the theory of the Israelite origin of the Qiang people, because the religious and cultural proofs used by Torrance Senior do not stand up to the rigours of historical research. ${ }^{18}$ His interpretation was not history is not the relation between history writing and reality but between history writing and evidence'. based on reliable evidence such as written sources or accepted oral traditions, but on theories regarding the lost tribes of Israel, couched in the evolutionary terms prevalent in the period (Parfitt \& Semi 2013:18; Wang 2002:138). This evaluation is consistent with Noll's remarks (1998) regarding the 'premodern' period. Even if the 1986 Israeli theory that the Qiang are descendants of Joktan can be proved, it was anachronistic for Torrance Senior to attribute to the Qiang a concept of the priestly mission of Israel to China through the Mosaic covenant, as Joktan was not a direct ancestor in the line of Abraham. There was therefore some inconsistency in Torrance Senior's discourse regarding the Qiang.

It is not possible today to re-examine the religious rituals of the Qiang as the Torrance family observed them in the 1920s, because current Qiang cultic practice is polytheistic (Yu 2004) and shamanistic (Oppitz 2004). The only scientific proof regarding their origins is DNA evidence showing that the DiQiang migrated from Euro-Asia during the Bronze Age (Gao et al. 2015). This leaves the possibility of migration from the Middle East in the pre-Mosaic period open to further research. The best that can be postulated is therefore that the monotheism and blood sacrifices of the Qiang derived from the religious practices of the Semites in the post-Noahic period. However, in spite of this lack of hard evidence, some Jewish organisations continue to consider the Qiang as a 'lost tribe of Israel' and the ethnicity of the Qiang remains a point of contention. ${ }^{19}$

Nonetheless, the lack of scientific proof did not deter Torrance from his resolve to continue the evangelisation of the Qiang begun by his father. The significance of the mission of Israel had been imprinted on the young Torrance's theological consciousness from his interaction with the Qiang. His theological studies had further convinced him of the significance Israel's history in the mission purposes of God (Torrance 1992:5). From his understanding of the priestly mission of Israel to the nations, Torrance built a biblical and systematic theology of the missio Dei through the covenant, encompassing both Israel and the church of Christ, realised in and through the incarnation. Mission to the Qiang is therefore the initial point at which Torrance's theology of the missional nature of divine-human communion and his personal mission practice intersect. In order to evaluate this further, the missional nature of Torrance's theology of divinehuman communion is now considered.

\section{The missional nature of divine-human communion in Torrance's theology Union with Christ and the missio Dei}

For Torrance (2008:164), the union of God and humanity in Christ properly belongs to the sphere of mystery, because it exposes a dimension of depth that cannot be fully comprehended by the human mind. This mystery is expressed in the New Testament using the categories mysterion, prothesis

19.In 1991, the Nahum Goldmann Museum of Jewish Diaspora in Tel Aviv included the Qiang in an exhibition. Chinese and Jewish websites continue to differ on their interpretation of the origins of the Qiang. 
and koinonia that give a theological dimension to the concepts of union and communion. Prothesis [purpose] conveys the eternal nature of the missio Dei set forth in Christ; mysterrion [mystery] communicates the mission of Christ on earth; and koinonia [communion] is the goal of mission as the communion of the church with the triune God - both now and in eternity (Torrance 2008:164-174).

\section{Prothesis}

Prothesis gives the mystery of union with Christ an eternal dimension. Firstly, it constitutes God's eternal purpose in the election of Christ to restore all things in heaven and earth to himself through the incarnation (Torrance 1960:86). This missional purpose is situated ontologically within the interpersonal relations of love that constitute the Trinity and reach out economically in space-time through the incarnation to restore all humanity to a relationship of union and communion with God. Thus, it relates to the eternal purpose of God for humanity in Christ from predestination to future glory (Torrance 2008:169). Secondly, prothesis speaks of the liturgical 'setting forth' of Christ as a propitiation for sin. For Torrance (2008:169-171), the Pauline concept of justification by grace through the redemption in Jesus Christ is reminiscent of the mercy seat (hilastērion) in Exodus and Leviticus, where the blood of the covenant is 'set forth' for atonement and becomes the basis for covenant relationship with God. Torrance therefore locates the essence of the missio Dei in the eternal divine will to bring humanity into a relationship of union with Christ (Torrance 2008:170).

\section{Mystērion}

Mysterrion incorporates the nature of spiritual and corporeal union with Christ. In the gospels Jesus holds this as the 'messianic secret' that is gradually, though not fully, revealed through the teaching of the parables (Torrance 1960:61). This secret belongs to those who inherit the kingdom and who come to know Christ. For Torrance (2002:108; 2008:74), 2 Corinthians 8:9 summarises the messianic secret: 'For you know the grace of our Lord Jesus Christ, though he was rich, yet for your sakes he became poor so that by his poverty you might become rich'. This verse encompasses five areas of mystêrion: faith, grace, hypostatic union, condescension and substitution.

Union with Christ is based on a relationship of faith as the gracious gift of God. The Corinthian Christians have a personal knowledge (ginōskō) of the grace of God that has brought them into a relationship of union with God by faith in Christ. In all Torrance's work, the mystery of faith as the gift of God is the basis for spiritual union with Christ (Torrance 2008:88). Spiritual union is given concrete conceptualisation by the covenant of grace that operates from Genesis to Revelation to restore estranged humanity to relationship with God through Christ. Torrance (2008:44) argues that the covenant is seminal to understanding the mystery of Christ, because it grounds the incarnation in space and time through the history of Israel. The covenant creates a 'bond' between the mission of the ontological Trinity as the missio Dei and the mission of the economic Trinity as the missio Dei realised in space-time in the hypostatic union.

The mystery of the hypostatic union is expressed by the designation of the Lord Jesus Christ as kurios, the Greek equivalent of YHWH. The key to Torrance's christology is his understanding of the unitary nature of the Father/Son relationship as expressed by the Greek couplets: anhypostasia and enhypostasia. By anhypostasia Torrance (2009:84) demonstrates that Christ's assumption of human nature had no existence outside union with God, meaning that Christ was truly God. By enhypostasia he shows that Christ's human nature was given real substance, meaning that he was truly human. This union of God and humanity in Christ then gives soteriological substance to the condescension of Christ who gave up his 'riches' in order to become poor that Torrance (2008:77) understands as a movement of descent into the world in order to lift the world up to union with God. This mystery of the covenant love of God, who freely chooses to interact with the world through the emptying of himself, is not an act of kenosis, but the voluntary veiling of himself in an act of condescension for the sake of the world (Torrance 2008:76).

From the anhypostasia-enhypostasia couplet, Torrance draws a doctrine of incarnational substitution made effective through the homoousion..$^{20}$ Christ's humiliation in the incarnation was 'for your sakes', showing that it had substitutionary implications. This is the 'wondrous exchange' in which Christ 'took our place and accomplished what we could not do' (Torrance 2009:123). In the Epilogue to Atonement, Torrance (2009:437 447) draws on his experience in China to illustrate the substitutionary nature of the incarnation. Recalling the grossly disfigured features of the Chengdu lepers, Torrance borrows from Irenaeus the concept that Christ assumes and converts leprous humanity by taking onto himself the disfigurement and degradation of human sin and substitutes for it his own perfect, covenant-keeping life. In union with Christ, the leprous sinner is given Christ's righteousness, is buried with him and raised to eternal life. ${ }^{21}$

The point that Torrance (2009:439-441) makes is that Christ assumed and transformed the whole human being, diseased mind and body and converted it through his own life of holiness and purity of mind. The idea of the conversion of leprous humanity draws the reader close to the personal core of Torrance's theological raison d'etre. This is the 'fundamental' patristic principle that 'The unassumed is the unhealed' (Gregory of Nazianzus) or 'What Christ has not assumed has not been saved' (Cyril of Alexandria). It is the essence of what

$20 . T h i s$ does not mean that Torrance negated forensic atonement. Torrance $(2002: 166$ 2009:68) argued for both a forensic and incarnational interpretation of the atonement.

21.In an editorial note on the Epilogue to Atonement (Torrance 2009:437-447, n.1) Walker comments that the essay encapsulates several themes central to Torrance's lectures and theology. These are the rationality of faith in Jesus Christ, the need for the transformation of the unbaptised human reason and the need for the church to evangelise the roots of human culture so that the gospel can take root. Walke ends with a pertinent comment, 'As an Epilogue, it also helps to give a more personal glimpse into the nature, challenge and task of theology as [Torrance] saw it. The personal nature of the essay, with its illustration from the Chengdu lepe colony, may also give insight into the way Torrance's thought processes were shaped by his early inter-cultural experiences. 
Torrance had learnt from H.R. Mackintosh and the substance of the personal transformation that occurred when he read Barth's account of the virgin birth (Torrance 2009:441-442).

It is precisely at this point of substitution that the mysterrion becomes the mystery concerning Christ and his church (Torrance 2008:166-167). Christ, who indwells his apostles by his Spirit, leads them into truth and makes them stewards of the mystery that through union with Christ, the church as the body of Christ is built into Christ, its head (Eph 4:16; Torrance 2008:168). This is initially fulfilled in the growth of the church through the missional proclamation of the gospel in the world and finally in the consummation of all things ( $R v 10: 7)$. In union with Christ the church therefore participates in the missio Dei that purposed in eternity to send Christ into the world and by means of the homoousion ensured that the hypostatic union of God and humanity in Christ made effective the substitutionary nature of the humiliation of Christ on the cross.

\section{Communion and the missio Dei}

\section{Koinōnia}

Koinōnia is communion with God made possible through the union between God and humanity in Christ and participation in the fellowship of the church (Torrance 1960:88). Koinonia therefore has both vertical and horizontal dimensions. This does not imply, however, a dualist distinction in the work of the Trinity, because both union with God in Christ and the communion of the saints in the Spirit are part of the same missional movement of perichoresis flowing from the Godhead (T.F. Torrance 2001:171, 192). It is the work of the Spirit to raise the church up into communion with God. Thus, the union of the church with Christ and the raising of the church into the communion of the Trinity form the essence of the mystery of Christ (Torrance 1959a:cvi). From this relationship of union and communion, all the blessings of God in Jesus Christ flow to the church as outcomes of both 'carnal union' with Christ in his life and death, and 'spiritual union' with Christ through the cleansing obtained by his blood in the atonement. In Torrance's theology, this relationship between Christ and the church has strongly covenantal overtones. The covenant is the point of entry into communion with God and the focus of the heaven/earth relationship made possible through the homoousion. It is therefore the locus of the missio Dei.

\section{Covenant and Church}

For Torrance (1959b:214) the nature and the mission of the church are of necessity interrelated. The church continues the 'apostolic succession' or the mission of Christ, because Christ is the 'Apostle from the Father' and, as such, he commissions and sends out his church in the same apostolic mission (Jn 20:21-23). ${ }^{22}$ Torrance (1992:4-5) argues that when the apostles and Early Church fathers reflected on the incarnation

22.In an article on the mission of the church Torrance (1966.130) writes, it is through union and communion with Him actualized in the Spirit that the Church is union and communion with Him actualized in the Spirit that the Church is
quickened into life as his living body on earth and is empowered in its apostolic mission to be His representative among men'. in the light of the homoousios of Jesus Christ with the Father, they understood it as the breaking of the eternal logos into history. They were therefore able to interpret the covenant history of Israel as the precursor of the incarnation and Jesus Christ as its fulfilment. It revealed to them that Israel had a role to play in the mission of God for the salvation of the world as the Suffering Servant and the precursor of the incarnation.

This concept of the missional role of Israel as God's covenant people plays a key role in Torrance's ecclesiology. The missional role of the Suffering Servant that Torrance (1992:5-46) assigns to Israel as God's covenant people in the post-resurrection period is unusual. Torrance (1992:37-42) argues that Israel and the Christian church have different roles to play. The church carries the message of the triumph of the cross into history, but the 'Jewish church' carries the dark side of the cross into history through its role as the 'scapegoat' that is cast out and 'scattered over the earth' ${ }^{23}$ For the church, the atonement is a finished work, but for the Jews, the atonement is 'divinely prolonged into history' through their suffering until they accept the Messiah. Thus, both the Christian church and the 'Jewish church', although currently divided, have a missional role to play in the history of the last days. For Torrance (1992:38-39), the holocaust has begun to open Christians' eyes to the missional role of Israel as the scapegoat that is now 'drawn into the heart and centre of Calvary' through suffering, giving the church a new conception of Israel's role in the atonement.

Colyer (2001:68. n. 50) finds Torrance's argument that the vicarious role of Israel in the mediation of reconciliation continues in the present age, 'astonishing' as well as 'insightful'. It can only be understood when considered within the context of Torrance's interaction with the Qiang. Torrance Senior's claim (1937) that the Qiang were ancient Israelites sent to bear witness to the need for atonement through blood sacrifice was based on their scapegoat ceremony that he interpreted as the Azazel ceremony of Leviticus 16 (Parfitt \& Semi 2013:20-21). T.F. Torrance's endorsement (1988) of the second edition of his father's book shows that, although the authenticity of the Jewish origins of the Qiang could not be established, he supported his father's understanding of the missional role of the Israelites in the world. ${ }^{24}$ Torrance's own interaction with the mission history of the Qiang bore witness to their suffering and rejection at the hands of the Han Chinese in their pre-Christian times and at the hands of the Long March's armies in the years following their acceptance of the Christian gospel. Thus, the Qiang continued their vicarious mission as Suffering Servant among the Chinese, even after they had accepted the Messiah (Torrance 1913-2007, Manuscript Collection Box 87).

23.Torrance does not cross-reference this allusion to Leviticus 16, but it seems that this is what he has in mind.

24.I am convinced ... that the origins of the Chi'ang and their religion lie deep in antiquity, in the pre-history of ancient Israel .. What I find particularly startling however, is that the religious observances of the Chi'ang seem to derive from a period in Israel's history before Moses, and certainly before the centralisation of period in Israel's history before Moses, and certainly before the centralisation of
the cult in Jerusalem had been carried out, when high place worship was still prevalent' (Torrance 1988:vii). 
It is Torrance's espousal of the missionary role of the Qiang as ancient Israelites in China, rather than the historical proofs of their origin, that is of significance for this research. Torrance's understanding (2009:117) of the participation of the Qiang as Israelites in the missio Dei resonates with his understanding of the relationship of continuity and discontinuity between the covenant people of God in the Old and New Testament. In the Old Testament, the relationship between $\mathrm{YHWH}$ and his people was concretised through the covenant with the missional purpose of bearing witness to the nations of the holiness of God. The failure of Israel to keep its side of the covenant led to the sending of the Messiah, fully homoousios with the Father, to make atonement for the sin of the world with his own life and blood, bringing in the new covenant in Christ. For Torrance atonement has therefore both incarnational and forensic application. Christ becomes both the fulfilment of the covenant from the side of God and the covenant keeper from the side of humanity (Torrance 2009:69).

Under the new covenant, the creation of the church is a function of the work of the Holy Spirit who forms the empirical community of people who are called into being by the gospel, indwelt by the Spirit and in union with Christ are joined to God (Torrance 1997:253). In Christ and by the Spirit the church participates in the communion of love that is the essence of the Trinity and therefore participates in the outflowing of the love of God to the world in the mission of Christ. This is not to equate the church with the mission of Christ, but to understand the missional task of the church as the realisation of the new covenant in practice (Torrance 1960:13-20). ${ }^{25}$ For Torrance (2012:84) there is thus no church without mission.

\section{Conjunction of theology and mission practice through the missio Dei}

Consideration of Torrance's biography, together with his theology of divine-human communion, shows that there is a common concern with mission in both. Torrance's covenantal theology sees divine-human communion as the goal of the missio Dei. In the same way, Torrance's personal biography displays an understanding of the church's task to participate in the missio Dei. In this final section, the conjunction of theology and mission practice draws conclusions for Torrance scholarship.

\section{Holism}

Colyer $(2001: 25,28)$ proposes that there is an 'architectonic holism' in Torrance's thought that allows for no dualism. ${ }^{26}$

25.The church is ontologically grounded in the Trinity through the communion of the Holy Spirit. This is expressed in the New Testament through the image of the church as the body of Christ that has the meaning of 'the whole Christ who include the church within his own fullness'. This does not mean that the church is Christ, because Christ is infinitely more than the church. Therefore, the New Testament because Christ is infinitely more than the church. Therefore, the New Testament also speaks of Christ as the head of the body that is the church. The being and nature of the church are inseparable from its mission, that is its sending by Chris (Torrance 2009:358-373).

26.This proposal has not gone unchallenged. For accusations of dualism in Torrance's theology, see Morrison (1995), Cassidy (2008) and Chiarot (2012).
However, without consideration of Torrance's personal mission practice, the potential still exists for a residual dualism to develop within Torrance scholarship (McGrath 1999:237). Torrance's unitary sense of the missio Dei and the mission of Christ through the evangelistic outreach of the church unite his theology and practice in a holistic way that gives personal credence to his lifelong struggle against the dualism of Western culture. ${ }^{27}$ Undeniably, there is a theological necessity for a unitary understanding of the Christian gospel through the homoousion in all Torrance's work, but it is also conceivable that Torrance's early exposure to the holism of the Chinese worldview opened him up to the possibility of different patterns of theological thought. ${ }^{28}$ In other words, Torrance's exposure to evangelical mission practice in China as a child may have instilled in him a penchant towards a unitary approach to theology that was able to flourish as he studied under Mackintosh, Barth and Lamont, and as he read the early Church Fathers. ${ }^{29}$ Under the influence of his theological mentors, it enabled him to develop an integrative trinitarian theology, centred in the homoousial relation of the Father, Son and Holy Spirit through which the incarnation acts as an axis intersecting space and time (Torrance 1969:72,74). The realism of the incarnation as an historical event means that theology can never be confined to the realm of the abstract, but always has outcomes in the practice of mission. ${ }^{30}$

\section{Practical outcomes}

For Torrance (1993:2-6) the biblical theological roots of the practical and missional nature of divine-human communion are found in Israel's role as 'royal priesthood' and bearer of cult and torah among the nations. As Israel could not remain faithful to its calling, Christ was sent into the world as the one elect of God to make atonement by his vicarious life and death for the sins of the whole world. The homoousion of the Son with the Father gives soteriological efficacy in the hypostatic union, and the homoousion of the Spirit with the Son and the Father enables the Spirit to lift up the church of Christ into union and communion with the triune God and one another as koinonia. This is the mission of Christ that is continued by the church as it engages in its practical task of proclaiming the gospel and bringing the kingdom of God in the world (Torrance 1966:137-138).

The practical nature of the gospel sends Torrance's theology out to proclaim the good news of salvation. For this reason, Torrance's theology is always both evangelical (Wordcentred) and evangelising (proclamation-based). It has practical outcomes for the life of the pastor and the theological educator for whom the primary task is to engage in theology

27.See Torrance (1980:15-43) for discussion on the dualist foundations of Western philosophy.

28.D.W. Torrance (2001:8), for example, speaks of T.F. Torrance's ability to adapt to Middle Eastern culture. For the patterns of the Chinese worldview, see Nisbett (2004).

29.Torrance's (1996) doctoral thesis, completed in 1948, was The Doctrine of Grace in the Apostolic Fathers.

30.D.W. Torrance (2001:13): 'For Tom, theology must be tested and born out in the Christian life'. His experiences as padre in the British Army during the Italian Christian life'. His experiences as padre in the British Army during the Italian
Campaign (1943-1945), 'reinforced the need for complete harmony between theology, preaching and daily life. Anything else was "paper theology"'. 
as mission. In Torrance's own life, this meant evangelising Western culture and participating in the resurrection of the Chinese church. It also gave Torrance and his brother David a concern for mission to Jews in Israel (Torrance 1986). Torrance does not engage directly with the practice of mission in his work and can thus not be labelled a 'missiologist'. However, his theology of divine-human communion is saturated with missional outcomes that are lived out in his lifelong engagement in mission in China (D.W. Torrance 2001:5). The practical outcomes of Torrance's theology are therefore to be found in his personal mission history.

\section{Conclusion}

Torrance's mission engagement with the Qiang in China should not be seen just as 'bookends' to his life, but as the realisation of his lifelong call to the integration of theology and mission practice. Mission to the Qiang is therefore the place in which Torrance's theology and biography conjoin. Firstly, the Torrance family's participation in the evangelical mission movement in China among the Qiang led to early experience of an evangelical mission mindset that, by his own admission, never left him. The preoccupation with mission saturates all his work. Secondly, participation in the evangelism of the Qiang exposed Torrance to the concept of the ancient Israelites' mission to China and a biblical theology of Israel's mission in spite of inconsistencies in the narrative and lack of scientific proof. It led him to a theology of the Israelites' continued mission in the world and gave the whole family a sense of the church's mission of the Jews. Thirdly, childhood assimilation into a unitary Chinese culture may, on the level of worldview, have opened Torrance up to the possibility of a more holistic view of theology that considers the perichoretic inter-trinitarian relations as the source of the missio Dei. The missio Dei is realised soteriologically in the incarnation by means of the homoousion through which the church is raised up to God in one movement of communion in union with Christ through the koinonia of the Holy Spirit.

As a result, Torrance's life and theology are both intensely missional. Torrance's theology of divine-human communion considers the one covenant of grace as the practical outworking in space-time of the missio Dei. His personal mission practice concentrated on the proclamation of the gospel both at home and in China. His visits to Chengdu, his facilitation of the Nanjing Bible printing press and his attempts to rebuild the Qiang church show that Torrance was not a theologian in the abstract. Therefore, attention to the significance of his mission work among the Qiang will enable future scholarship to consider Torrance's mission practice as integral to and not separate from his theology of the missional nature of divine-human communion.

\section{Acknowledgements Competing interests}

The authors declare that they have no financial or personal relationships which may have inappropriately influenced them in writing this article.

\section{Authors' contributions}

The subject matter is drawn from a $\mathrm{PhD}$ thesis submitted to North-West University, Potchefstroom campus. Seed, Caroline G., 2016, The missional nature of divine-human communion: T.F. Torrance and the Chinese church. PhD thesis, Faculty of Theology, North-West University, Potchefstroom.

D.L. was the promoter and R.F. was the co-promoter.

\section{References}

Bosch, D.J., 1991, Transforming mission: Paradigm shifts in theology of mission, Orbis, New York.

Cassidy, J.J., 2008, 'T.F. Torrance's realistic soteriological objectivism and the elimination of dualisms: Union with Christ in current perspective', Mid-America Journal of Theology 19, 165-194.

Chiarot, K., 2012, The unassumed is the unhealed: The humanity of Christ in the theology of T.F. Torrance', PhD thesis, School of Divinity, History and Philosophy, Aberdeen University, Aberdeen.

Church Missionary Society Archive, 1869-1949, section 1, East Asia Missions, part 1. (microfiche).

Colyer, E.M., 2001, How to read T.F. Torrance: Understanding his trinitarian and scientific theology, InterVarsity Press, Downers Grove, IL.

Donnithorne, V.H., 1922, 'An opportunity for mission pioneers', The Church Missionary Outlook 49(6), 111-114, viewed 30 July 2015, from http://www. churchmissionarysociety.amdigital.co.uk/Documents/Images/CMS_OX_ Outlook_1922_06/0

Gao, S.Z., Zhang, Y., Wei, D., Li, H.J., Zhao, Y.B., Cui, Y.Q. et al., 2015, 'Ancient DNA reveals a migration of the ancient Di-qiang populations into Xinjiang as early as the Bronze Age', American Journal of Physical Anthropology 157(1), 71-80. http:// dx.doi.org/10.1002/ajpa.22690

Graham, D.C., 1958, The customs and religion of the Ch'iang, Smithsonian Institute, Washington, DC. (Smithsonian Miscellaneous Collections vol. 135(1)).

Hanna, M.F., 2004, 'The use of science in theology: Case studies of Thomas F. Torrance and Langdon B. Gilkey', PhD thesis, Andrews University, Seventh Day Adventist Theological Seminary, Berrien Springs, Ml

Latourette, K.S., 1929, A history of missions in China, Society for the Promotion of Christian Knowledge, London.

McClendon, J.W., 2002, Biography as theology: How life stories can remake today's theology, Wipf \& Stock, Eugene, OR.

McGrath, A., 1999, T.F. Torrance: An intellectual biography, T\&T Clark, Edinburgh

Morrison, J.D., 1995, 'Thomas Forsyth Torrance's critique of evangelical (protestant) orthodoxy', The Evangelical Quarterly 67(1), 53-69.

Munchin, D., 2011, Is theology a science? The nature of scientific enterprise in the scientific theology of Thomas Forsyth Torrance and the anarchic epistemology of Paul Freyerabend, Brill, Leiden.

Nisbett, R., 2004, The geography of thought: How Asians and Westerns think differently ... and why, Free Press, New York.

Noll, M., 1998, 'The potential of missiology for the crises of history', in R. Wells (ed.), History and the Christian historian, pp. 106-123, Eerdmans, Grand Rapids, MI.

Oppitz, M., 2004, 'Ritual objects of the Qiang Shamans', Anthropology and Aesthetics $45,10-46$.

Parfitt, T. \& Semi, E.T., 2013, Judaising moments: Studies in the margins of Judaism in modern times, 2nd edn., Routeledge, London.

Tamn, M., 2014, 'Truth, objectivity and evidence in history', Journal of the Philosophy of History 8, 265-290.

Tiénou, T. \& Hiebert, P.G., 2005, 'From systematic and biblical to missional theology', in C.H. Kraft (ed.), Appropriate Christianity, pp. 117-134, William Carey, Pasadena, CA.

Torrance, D.W., 2001, 'Thomas Forsyth Torrance: Minister of the gospel, pastor and evangelical theologian', in E.M. Colyer (ed.), The promise of Trinitarian theology: Theologians in dialogue with T.F. Torrance, pp. 1-30, Rowman \& Littlefield, Lanham, MD.

Torrance, D.W., n.d., You're included, interview transcript, viewed 14 May 2015, from http://www.gci.org/files/D.Torrance.pdf

Torrance, D.W. (ed.), 1986, The mission of Christians and Jews, Hansel, Haddington.

Torrance, T., 1920, The history, customs and religion of the Ch'iang: An aboriginal people of west China, Shanghai Mercury, Shanghai.

Torrance, T., 1937, China's first missionaries: Ancient Israelites, Thynne, London.

Torrance, T., 1988, China's first missionaries: Ancient Israelites, 2nd edn., ed. T.F. Torrance, D. Shaw, Chicago, IL.

Torrance, T.F., 1913-2007, 'Thomas F. Torrance Manuscript Collection', Specia Collections, Princeton Theological Seminary Library, Princeton, NJ.

Torrance, T.F., 1959a, The school of faith: The catechisms of the reformed churches, transl. Thomas F. Torrance, James Clark, London. 
Torrance, T.F., 1959b, Conflict and agreement in the church: Order and disorder, vol. 1, Lutterworth, London.

Torrance, T.F., 1960, Conflict and agreement in the church: The ministry and the sacraments of the gospel, vol. 2, Lutterworth, London.

Torrance, T.F., 1966, 'The mission of the church', Scottish Journal of Theology 19(2), 129-143. http://dx.doi.org/10.1017/S0036930600002921

Torrance, T.F., 1969, Space, time and incarnation, T\&T Clark, Edinburgh.

Torrance, T.F., 1980, The ground and grammar of theology, Christian Journals, Belfast. Torrance, T.F., 1992, The mediation of Christ, 2nd edn., T\&T Clark, Edinburgh.

Torrance, T.F., 1993, Royal priesthood: A theology of ordained ministry, 2nd edn., T\& Clark, Edinburgh.

Torrance, T.F., 1996, The doctrine of grace in the Apostolic Fathers, Wipf \& Stock Eugene, OR. (The Torrance Collection).

Torrance, T.F., 1997, The Trinitarian faith: The evangelical theology of the ancient Catholic Church, 2nd edn., T\&T Clark, Edinburgh.

Torrance, T.F., 1982, Reality and evangelical theology: The realism of Christian revelation, InterVarsity Press, Downers Grove, IL.

Torrance, T.F., 2001, 'Thomas Torrance responds', in E.M. Colyer (ed.), The promise of Trinitarian theology: Theologians in dialogue with T.F. Torrance, pp. 303-340, Rowman \& Littlefield, Lanham, MD.

Torrance, T.F., 2002, The doctrine of Jesus Christ, Wipf \& Stock, Eugene, OR. (The Torrance Collection).
Torrance, T.F., 2005, 'Thomas Torrance 1871-1959', in Biographical Dictionary of Chinese Christianity, viewed 28 April 2016, from http://www.bdcconline.net/en/ stories/t/torrance-thomas.php

Torrance, T.F., 2008, Incarnation: The person and life of Christ, ed. R.T. Walker, InterVarsity Press, Downers Grove, IL.

Torrance, T.F., 2009, Atonement: The person and work of Christ, ed. R.T. Walker, InterVarsity Press, Downers Grove, IL.

Torrance, T.F., 2012, Gospel, church and ministry, ed. Jock Stein, Thomas F. Torrance Collected Studies (1), Pickwick, Eugene, OR.

Walls, A., 1996, The missionary movement in Christian history: Studies in the transmission of faith, Orbis, New York.

Wang, M.K.E., 2002, 'Searching for Qiang culture in the first half of the twentieth century', InnerAsia 4(1), 131-148. http://dx.doi.org/10.1163/146481702793647588

Wright, C.J.H., 2006, The mission of God: Unlocking the Bible's grand narrative, InterVarsity Press, Leicester.

Yom, A., 2013, 'Rethinking scientific theology from a pneumatological perspective: Towards constructing a triadic analogical approach to theological science in dialogue with T.F. Torrance', PhD thesis, School of Divinity, Regent College, Vancouver.

Yu, S.-L., 2004, 'Sacrifice to the mountain: A ritual performance of the Qiang minority people in China', The Drama Review 48(4), 155-166. http://dx.doi.org/10.1162/ 1054204042442035

Ziegler, G., 2008, 'Reflections on the importance of the theology of Rev. Prof. T.F. Torrance for the life and mission of the church', Princeton Theological Review 39(14), 23-26. 